\title{
APLIKASI GAME EDUKASI FIQIH KELAS 2 MADRASAH IBTIDAIYAH BERBASIS ANDROID
}

\author{
Afrizal Umar ${ }^{1}$, Wanti Rahayu ${ }^{2}$ \\ Program Studi Teknik Informatika, Fakultas Teknik dan Ilmu Komputer, \\ Universitas Indraprasta PGRI \\ Jalan Raya Tengah No 80, Kelurahan Gedong, Pasar Rebo, Jakarta Timur \\ Icay77@gmail.com ${ }^{1}$,wanti.unindra27@gmail.com ${ }^{2}$
}

\begin{abstract}
Abstrak
Di Zaman sekarang ini perkembangan teknologi informasi terutama di Indonesia semakin bertambah maju. Namun masih kurang tersedianya suatu aplikasi mobile tentang pembelajaran pendidikan agama islam (PAI). Informasi yang terdapat pada buku-buku pun terbatas, sehingga, tidak dapat dimanfaatkan dengan baik dan membuat kurangnya minat membaca bagi siswa sekolah juga masyarakat umum.Tujuan penelitian ini adalah membuat sebuah aplikasi pembelajaran fiqih yang lebih menarik dengan menggunakan media smartphone secara digital sehingga mudah di akses kapanpun, dimanapun dan memberikan informasi pembelajaran yang efektif dan efisien secara offline.Selain itu, masyarakat umum dapat merasakan kemudahan dalam mengolah data untuk mengaksesnya. Metode penelitian yang digunakan aplikasi ini adalah metode grounded (grounded research), dari hasil penelitian dapat mengasah dan menambah pengetahuan serta wawasan tentang materi pembelajaran fiqih kelas 2 madrasah ibtidaiyah.
\end{abstract}

Kata Kunci: Game, Android, Fiqih, Edukasi

\begin{abstract}
In today's era, the development of information technology, especially in Indonesia, is increasingly advanced. However, there is still a lack of availability of a mobile application about learning Islamic religious education (PAI). The information contained in books is also limited, so it cannot be used properly and creates a lack of interest in reading for school students and the general public. The purpose of this study is to create a more interesting fiqh learning application using digital smartphone media so that it is easy to access anytime, anywhere and provide effective and efficient learning information offline. In addition, the general public can feel the ease of processing data to access it. The research method used by this application is the grounded method (grounded research), from the results of the research it can hone and increase knowledge and insight into fiqih learning materials for class 2 madrasah ibtidaiyah.
\end{abstract}

Keywords: Game, Android, Fiqh, Education

\section{PENDAHULUAN}

Pada zaman yang berbasis teknologi seperti sekarang ini setiap anak pasti mengetahui apa itu game, kebanyakan dari mereka sangat menyukai game baik melalui komputer maupun handphone.Game edukasi adalah permainan yang telah dirancang untuk mengajar seseorang tentang topik tertentu atau membantu orang lain dalam belajar suatu keterampilan sambil bermain(Setiawan, Noorwatha I Kadek Dwi, 2020). Namun dalam kenyataannya mereka lebih memilih memainkan game-game yang tidak bermanfaat untuk menambah ilmu pengetahuan dan malah menjadi pecandu game sehingga lupa untuk belajar.

Citra game dimasyarakat masih dipandang sebagai media yang menghibur dibanding sebagai media pembelajaran. Salah satu faktor yang membuat game menjadi banyak peminatnya adalah sebarapa baik game itu dapat mudah untuk dimainkan. Game yang menarik bagi kalangan siswa dan mahasiswa adalah game yang berbasis pengetahuan.

Dalam perkembangannya game yang berbasis tes pengetahuan sudah cukup banyak beredar dan cukup banyak ragamnya. Namun game pengetahuan yang berisi tentang materi pembelajaran agama masih sulit ditemui. Hal tersebut membuat masyarakat kurang tertarik untuk mengasah kemampuan otak mereka dengan memainkan game berbasis pengetahuan yang berisi materi monoton.

Fiqih adalah salah satu bidang ilmu dalam syariat Islam yang membahas masalah hukum yang membahas berbagai aspek kehidupan muslim, kehidupan pribadi yang baik, kehidupan 
bermasyarakat dan kehidupan manusia dengan Tuhannya(Nasution \&Ginting, 2020). Contoh paling mudah adalah Fiqih Shalat tentang tata cara ibadah shalat dengan dalil-dalil / bukti yang termasuk dalam Al Qur'an dan Sunnah Rosul. Sunnah Rosul adalah segala sesuatu yang diriwayatkan dari Rasulullah Shallallahu Alaihi wa Sallam.

Secara etimologi / bahasa, fiqih artinya paham yang mendalam, pengertian, pengertian.Sementara menurut terminologi, istilah hukum hukum syar'i yang amali (praktis) diambil dari dali-dalil yang terinci. Dari uraian diatas, peneliti berupaya untuk membuat suatu game yang bertemakan islami yang berisikan tentang materi-materi fiqih kelas dua madrasah ibtidaiyah. Untuk itu peneliti mengambil judul Skripsi: "Aplikasi Game Edukasi Fiqih Kelas Dua Madrasah Ibtidaiyah Berbasis Android".

Penelitian ini diharapkan memberi manfaat untuk semua komponen yaitu siswa, guru, sekolah dan peneliti sendiri. Untuk siswa diharapkan dapat meningkatkan sikap positif siswa terhadap pelajaran Fiqih serta meningkatkan hasil belajar. Guru sebagai masukan bagi mata pelajaran khususnya Fiqih untuk dijadikan bahan pertimbangan dalam memilih model pembelajaran Fiqih dengan aplikasi Fiqih Quiz, sedangkan untuk sekolah diharapkan dapat menjadi salah satu bahan acuan bagi sekolah dalam rangka meningkatkan kualitas proses belajar mengajar khususnya mata pelajaran Fiqih.

Dengan dibantu aplikasi mobile berbasis android, ilmu pengetahuan dapat dikemasmenjadi bentuk yang lebih menarik(Fauzi\&Ismawan, 2020). Aplikasi ini akan membantu dan memudahkan pengguna dalammempelajari dan meningkatkan akan ilmu pengetahuan mata pelajaran fiqih .Aplikasi adalah suatu perangkat lunak yang dibuat sebagai front end sebuah sistem yang dipakai untuk mengelola data sehingga menjadi suatu informasi yang bermanfaat bagi pengguna(Fachri, 2020). Tujuan dari penelitian ini adalah untuk merancang sebuah media berupa aplikasi Android yang berisi materi pelajaran fiqih kelas 2 madrasah ibtidaiyah. Menurut (Enterprise, 2015), Android adalah sistem operasi berbasis Linux yang dirancang untuk perangkat seluler layar sentuh seperti telepon pintar dan komputer tablet. Android merupakan sistem operasi yang paling diminati di masyarakat karena memiliki kelebihan seperti sifat opensource yang memberikan kebebasan para pengembang untuk menciptakan aplikasi.Untuk saat ini aplikasi Android merupakan sistem yang digemari oleh masyarakat. Oleh karena itu, dengan berkembangnya penggunaan Android maka peneliti memutuskan membuat sebuah aplikasi pembelajaran agar memudahkan para siswa untuk mengakses materi pembelajaran fiqih kelas 2 secara efisien.

\section{PENELITIAN RELEVAN}

Penelitian yang relevan dilakukan sebagai referensi dalam pembuatan penelitian yang peneliti buat, adapun contoh penelitian dari jenis penelitian yang sama sebagai bahan pembanding dengan penelitian yang saat ini dilakukan. Berikut adalah ketiga daftar penelitian yang dilakukan oleh peneliti yaitu yang pertama adalah judul "Pengembangan game edukasi pengenalan nama hewan dalam bahasa inggris sebagai media pembelajaran siswa sd berbasis macromedia flash" nama peneliti yaitu Ghea Putri Fatma Dewi dan hasil penelitiannya adalahberupa aplikasi game edukasi pengenalan nama hewan dalam bahasa inggris sebagai media pendukung dalam kegiatan belajar mengajar antara guru dan peserta didik agar lebih mudah mencerna pelajaran dengan baik dibandingkan dengan metode pembelajaran yang sebelumnya(Dewi, 2012). Yang kedua adalah nama judul yaitu "Game Edukasi Pengenalan Alat Musik Tradisional di Indonesia Berbasis Android", nama peneliti yaitu Fahmi Rahim, dan hasil penelitiannyaadalah sebagai media pembelajaran yang interaktif yang dibutuhkan untuk siswa pengenalan budaya yang ada dan dapat dijadikan sebagai untuk memberikan wawasan kepada anak-anak (Rahim, 2016). Dan yang ketiga adalah nama judul yaitu "Game Edukasi Sebagi Media Pembelajaran Pendidikan Anak Usia Dini", nama peneliti yaitu Anik Vega Vitianingsih, dan hasil penelitiannya adalah berupa aplikasi mobile game sebagai media alternatif pembelajaran untuk mengenal simbol, berhitung, mencocokkan gambar dan menyusun acak kata(Vitianingsih, 2016).

\section{METODE PENELITIAN}

Metode penelitian adalah cara-cara ilmiah untuk mendapatkan data yang valid, dengan tujuan dapat ditemukan, dikembangkan, dan dibuktikan suatu pengetahuan tertentu, sehingga pada gilirannya dapat digunakan untuk memahami, memecahkan, dan mengantisipasi masalah(Efendi, Jonaedi, 
2018). Peneliti menggunakan metode penelitian menggunakangrounded research (penelitian berdasarkan pada fakta). Grounded research adalah suatu metode penelitian yang mendasarkan diri pada fakta dan menggunakan analisa perbandingan bertujuan untuk mengadakan generalisasi empiris menetapkan konsep-konsep. membuktikan teori dan mengembangkan teori di mana pengumpulan data dan analisa data berjalan pada waktu yang bersamaan (Riyanto, Wahyu Hidayat, 2020). Penelitian yang dilakukan bersifat evaluative. Peneliti hanya mencari dan mengumpulkan data, untuk melakukan klasifikasi terhadap data tersebut, mengolah, dan menganalisa data, membangun hipotesis menjadi teori. Dalam pengumpulan data peneliti menggunakan beberapa teknik pengumpulan data dalam penelitian antara lain:

\section{Studi Kepustakaan}

Pengumpulan data dan informasi dari kutipan-kutipan buku tentang pemrograman dan aplikasi game, Peraturan perundang-undangan, serta hasil laporan dan bahan lainnya yang berkaitan dengan penelitian ini. Bahan-bahan tersebut diambil teori-teori yang dapat dijadikan landasan untuk menganalisa masalah yang ditemukan dalam penelitian.

\section{Studi Lapangan}

Studi lapangan ini peneliti lakukan untuk melihat langsung terhadap sistem edukasi yang masih menggunakan sistem manual (buku bacaan), dalam studi lapangan dipergunakan teknik pengumpulan data antara lain dengan cara:

1. Wawancara

Melalui teknik ini akan diperoleh data dengan cara tanya jawab dengan masyarakat luar, Khususnya kepada siswa siswi kelas dua madrasah ibtidaiyah yang belum paham dan mengerti tentang game dengan tema pengetahuan Islami, wawancara ini dimaksudkan untuk memperoleh keterangan tentang permasalahan yang dibahas.

2. Survey

Survey adalah pengamatan dan pencatatan secara sistematik terhadap unsur-unsur yang tampak dalam suatu gejala atau gejala-gejala dalam objek penelitian.menurut (Hikmat, 2011:73), mendefinisikan survey sebagai pemilihan, pengubahan dan pengodean serangkaian perilaku dalam suasana yang sesuai dengan tujuan-tujuan empiris.Penelitimelakukan survey awal untuk mengumpulkan data-data yang dibutuhkan untuk analisa game dengan bertemakan pengetahuan Islami mulai bulan Maret.

3. Studi literature

Studi literatur berisi uraian tentang teori, temuan dan bahan penelitian lain yang diperoleh dari bahan acuan untuk dijadikan landasan kegiatan penelitian.Studi literatur dalam sebuah penelitian untuk mendapatkan gambaran yang menyeluruh tentang apa yang sudah dikerjakan orang lain dan bagaimana orang mengerjakannya.Peneliti mengumpulkan data dan mempelajari atau membaca pendapat ahli yang berhubungan dengan permasalahan yang akan diteliti untuk memperoleh data yang diperlukan, serta untuk landasan teori yang akurat dan menunjang.

4. Instrumen penelitian

Instrumen penelitian yang digunakan dalam pengumpulan data adalah alat perekam gambar seperti kamera digital yang berguna sebagai alat bantu pada saat observasi. Observasi memungkinkan peneliti memperoleh data data yang tidak diungkapkan oleh subjek penelitian secara terbuka dalam wawancara.

\section{HASIL DAN PEMBAHASAN}

Masalah yang dihadapi dalam membangun aplikasi Fiqih Quiz ini adalah bagaimana merancang aplikasi yang mampu membantu meningkatkan kualitas pembelajaran Fiqih untuk siswa kelas 2 MI serta mengatasi keterbatasannya media buku Fiqih kelas 2 di MI Assa`adiyah Attahiriyah.Aplikasi Fiqih Quiz merupakan salah satu alternatif pembelajaran bagi siswa dengan memanfaatkan telepon genggam sebagai sarana belajarnya.Pembelajaran pada dasarnya menggunakan media buku yang memiliki keterbatasan seperti mudah usang atau rusak, harganya cenderung mahal, tidak ramah lingkungan karena buku menggunakan kertas.Untuk itu perlu dibuat aplikasi Fiqih Quiz yang dapat digunakan selama pembelajaran Fiqih kelas 2, dalam hal ini di dalam sebuah telepon genggam yang telah memiliki dukungan Operating System Android. 


\section{Flowchart}

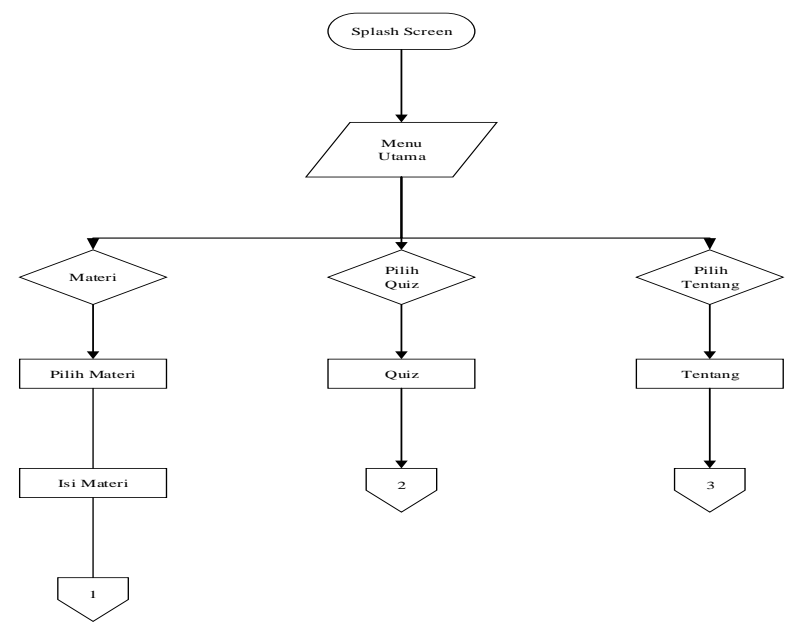

Gambar 1. Flowchart Menu Utama

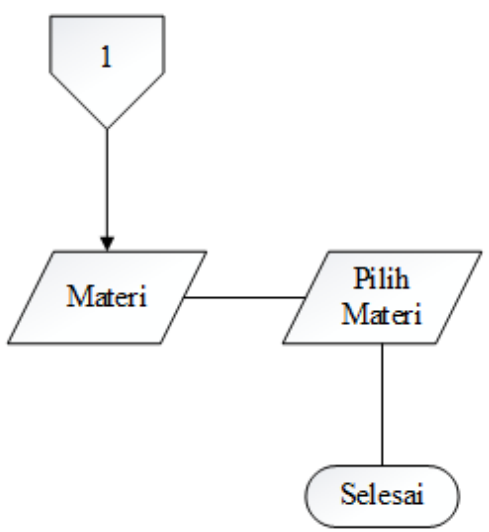

Gambar 2. Flowchart Menu Materi

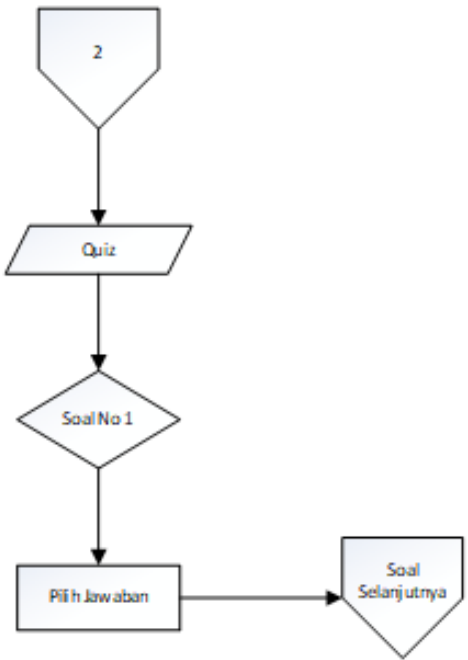

Gambar 3. Flowchart Menu Quiz 


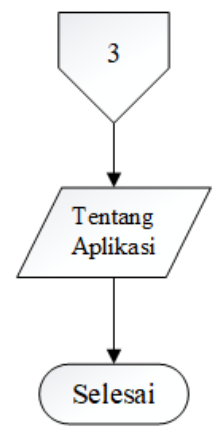

\section{Tampilan Aplikasi}

Gambar 4. Flowchart Menu Tentang Aplikasi

\section{Menu Utama}

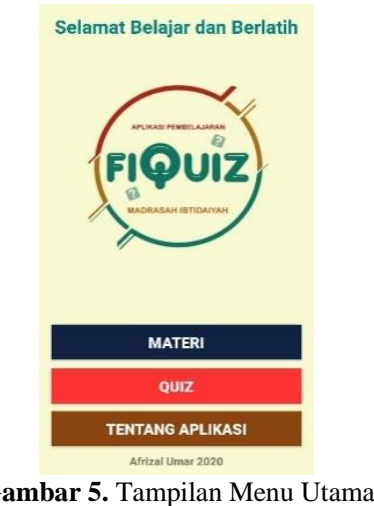

Gambar 5 adalah tampilan dari menu utama, dimana tampilan ini menampilkan menu yang ada pada aplikasi fiqih kuis, yang terdiri dari tiga tombol yaitu Materi, Quiz dan Tentang Aplikasi.

\section{Menu Pilih Materi}

\section{SHOLAT FARDU}

ADZAN DAN IQOMAH

SHOLAT BERJAMAAH

ZIKIR DAN DOA

Gambar 6. Tampilan Menu Pilih Materi

Gambar 6 adalah tampilan dari menu pilih materi, dimana tampilan ini berisikan tentang pilihan materi-materi yang dapat dipelajari sebelum pengguna menjawab soal-soal yang ada pada menu quiz.

\section{Menu Materi Sholat fardu}




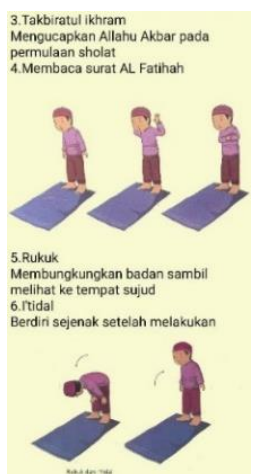

Gambar 7. Tampilan Menu Materi Sholat Fardu

Gambar 7 adalah tampilan dari menu materi sholat fardu, dimana tampilan ini berisikan materimateri sholat fardu yang dapat dipelajari sebelum pengguna menjawab soal-soal yang ada pada menu quiz.

\section{Menu Materi Adzan dan Iqomah}

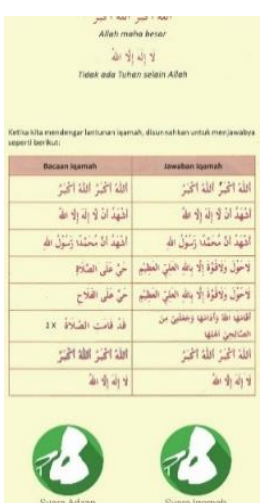

Gambar 8. Tampilan menu materi Adzan dan Iqomah

Gambar 8 adalah tampilan dari menu materi Adzan dan Iqomah, dimana tampilan ini berisikan materi-materi Adzan dan Iqomah yang dapat dipelajari sebelum pengguna menjawab soal-soal yang ada pada menu quiz.

\section{Menu Materi Sholat Berjamaah}

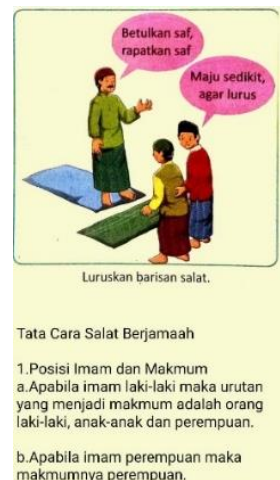

Gambar 9. Tampilan Menu Materi Sholat Berjamaah

Gambar 9 adalah tampilan dari menu materi Materi Sholat Berjamaah, dimana tampilan ini berisikan materi-materi Sholat Berjamaah yang dapat dipelajari sebelum pengguna menjawab soalsoal yang ada pada menu quiz. 


\section{Menu Materi Zikir dan Doa}

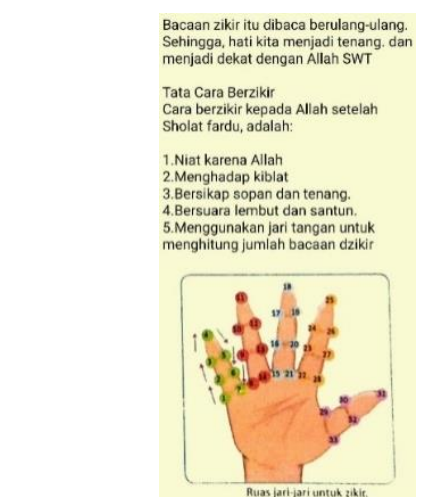

Gambar 10. Tampilan Menu Materi Zikir dan Doa

Gambar 10 adalah tampilan dari menu materi Materi Zikir dan Doa, dimana tampilan ini berisikan materi-materi Materi Zikir dan Doa yang dapat dipelajari sebelum pengguna menjawab soal-soal yang ada pada menu quiz.

\section{Menu Quiz}

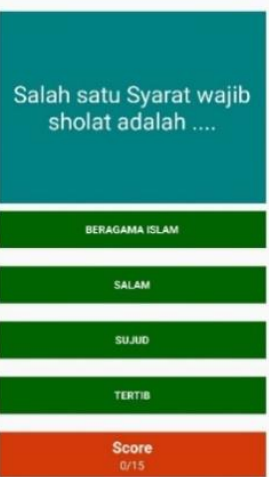

Gambar 11. Tampilan Menu Quiz

Gambar 11 adalah tampilan dari menu quiz, dimana tampilan ini akan menampilkan pertanyaanpertanyaan yang harus di jawab oleh pengguna.

\section{Tampilan Score}

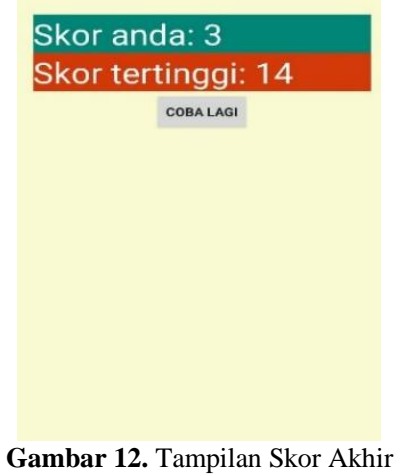

Gambar 12 adalah tampilan dari skor akhir, dimana tampilan ini akan menampilkan skor akhir hasil dari pertanyaan-pertanyaan yang berhasil di jawab oleh pengguna. 


\section{Menu Tentang Aplikasi}

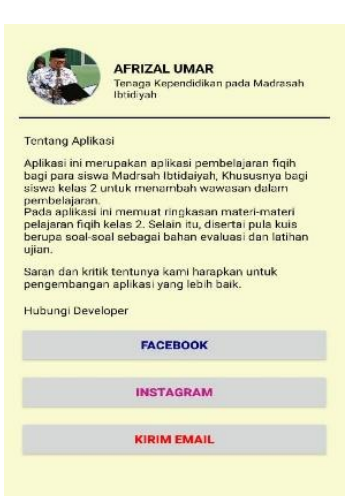

Gambar 13. Tampilan Menu Tentang Aplikasi

Gambar 13 adalah dari menu Tentang Aplikasi, dimana tampilan ini akan menampilkan profil singkat pembuat aplikasi.

\section{SIMPULAN}

Dari hasil penelitian yang dilakukan pada perancangan aplikasi game edukasi fiqih kelas 2 berbasis android dapat disimpulkan bahwa aplikasi media digital yang telah dirancang dan dibangun dengan tersistem atau terstruktur, dapat mengefisien pembelajaran dan mengatasi keterbatasan penggunaan media buku, memudahkan guru dalam melakukan penilaian kepada murid yang telah mengerjakan evaluasi melalui aplikasi tanpa harus menghitung manual. Dan pembelajaran Fiqih berbasis Android yang dapat di-install pada smarthphone bersistem operasi Android, dapat digunakan di mana saja sehingga membuat murid tertarik untuk mengikuti pelajaran Fiqih.

\section{DAFTAR PUSTAKA}

Dewi, G. P. F. (2012). Pengembangan Game Edukasi Pengenalan Nama Hewan Dalam Bahasa Inggris Sebagai Media Pembelajaran Siswa SD Berbasis Macromedia Flash. Universitas Negeri Yogyakarta.

Efendi, Jonaedi, J. I. (2018). METODE PENELITIAN HUKUM NORMATIF DAN EMPIRIS. PRENADAMEDIA GRUP. Enterprise, J. (2015). Mengenal Dasar-Dasar Pemrograman Android. Elex Media Komputindo.

Fauzi, Achmad, Fiqih Ismawan, H. I. D. (2020). APLIKASI PENGENALAN RAGAM CABANG OLAHRAGA BERBASIS ANDROID. JRAMI (Jurnal Riset Dan Aplikasi Mahasiswa Informatika), 1.

Nasution, Muhammad Ansori, Guidio Leonarde Ginting, E. R. S. (2020). Implementasi Algoritma Zhu-Takaoka Pada Aplikasi Syariat Islam Berdasarkan Ilmu Fiqih Berbasis Android. JOURNAL OF INFORMATION SYSTEM RESEARCH (JOSH), 1 .

Pane, Syafrizal Fachri, D. (2020). Membangun Aplikasi Peminjaman Jurnal Menggunakan Aplikasi Oracle Apex Online. Kreatif Industri Nusantara.

Rahim, F. (2016). Game Edukasi Pengenalan Alat Musik Tradisional Di Indonesia Berbasis Android. Universitas Islam Negeri Alauddin.

Riyanto, Wahyu Hidayat, A. M. (2020). Metodologi Penelitian Ekonomi. Universitas Muhammadiyah Malang.

Setiawan, Noorwatha I Kadek Dwi, D. (2020). Kapita Selekta Citraleka Desain 2020: Dialektika Seni, Desain, dan Kebudayaan Pada Era Revolusi Industri 4.0. STMIK STIKOM Indonesia (STIKI Press).

Vitianingsih, A. V. (2016). Game Edukasi Sebagai Media Pembelajaran Pendidikan Anak Usia Dini. Jurnal Ilmiah Universitas Dr. Soetomo Surabaya, 1. 